\title{
Association of Parasite Density and Hematological Parameters of Plasmodium vivax- and Plasmodium falciparum-infected Patients Attending Merauke General Hospital, Papua, Indonesia
}

\author{
Roy Bagus Kurniawan ${ }^{1}$, Puspa Wardhani ${ }^{2 *}$, Heny Arwati ${ }^{3}$, Aryati Aryati ${ }^{4}$, Trieva Verawaty Butarbutar ${ }^{5}$, \\ Christophorus Oetama Adiatmaja ${ }^{5}$, Amarensi Milka Betaubun ${ }^{5}$, Nur Chamidah ${ }^{6}$
}

\begin{abstract}
${ }^{1}$ Medical Doctor Study Programme, Faculty of Medicine, Universitas Airlangga, Jl. Prof. Dr. Moestopo No. 47 Surabaya, Indonesia; ${ }^{2}$ Department of Clinical Pathology, Faculty of Medicine, Universitas Airlangga/Dr. Soetomo General Academic Hospital, Jl. Prof. Dr. Moestopo No. 47 Surabaya, Indonesia; ${ }^{3}$ Department of Medical Parasitology, Faculty of Medicine, Universitas Airlangga, Jl. Prof. Dr. Moestopo No. 47 Surabaya, Indonesia; ${ }^{4}$ Department of Clinical Pathology, Faculty of Medicine, Universitas Airlangga/Dr. Soetomo General Academic Hospital, JI. Prof. Dr. Moestopo No. 47 Surabaya, Indonesia; ${ }^{5}$ Department of Clinical Pathology, Clinical Pathology Specialist Study Programme, Faculty of Medicine, Universitas Airlangga/ Dr. Soetomo General Academic Hospital, JI. Prof. Dr. Moestopo No. 47 Surabaya, Indonesia; ${ }^{6}$ Department of Mathematics, Faculty of Sciences and Technology, Universitas Airlangga, J. Mulyorejo Surabaya, Indonesia
\end{abstract}

Edited by: Ksenija Bogoeva-Kostovska ardhani P, Arwati H, Arya Aryati, Butarbutar TV, Adiatmaja CO, Betaubun AM matological Parameters of Plasmodium vivax- and Plasmodium falciparum-infected Patients Attending Merauke General Hospital, Papua, Indonesia Open Access Maced J Med Sci. 2020 Oct 10; 8(B):825-831. https://doi.org/10.3889/oamjms.2020. 488 ds: Parasite density; Hematology; Malaria; Plasmodium vivax; Plasmodium falciparum
"Correspondence: Puspa Wardhani, Department of Clinical Pathology, Faculty of Medicine, Universitas Clinical Pathology, Faculty of Medicine, Unic Soetomo General Academic Hospital Jl. Prof. Dr. Moestopo No. 47 Surabaya, Indonesia Ne: +628123176937. E-mail: puspa_pk@yahoo.co.id Revised: 24-Sep-2020 Accepted: 28-Sep-2020
Copyright: $\odot 2020$ Roy Bagus Kurniawan, Puspa Wardhan Heny Arwati, Aryati Aryati, Trieva Verawaty Butarbutar, Christophorus Oetama Adiatmaja, Amarensi Milka Betaubun, Nur Chamidah Funding: The funding of this research was from the Ministry of Research, Technology, and Higher Education of the Republic of Indonesia with contract number: 544/ N3.14/LT/2019. Competing Interests: The authors have declared that no
competing interests exist under the terms of the Creative Commons Attribution-

\begin{abstract}
BACKGROUND: Plasmodium falciparum and Plasmodium vivax are frequent causes of malaria. Although they are blood parasites, their biological characteristics are dissimilar, and their species-related consequences on hematological parameters have not been widely investigated. They might be valuable to distinguish both species infection, notably for an endemic region with limited diagnostic resources.

AIM: This study aimed to know the species-specific effect on hematological parameters and its correlation to the parasite density in P. vivax- and P. falciparum-infected patients attending Merauke General Hospital, Papua Indonesia.

MATERIALS AND METHODS: Malaria patients confirmed by blood film microscopy from January 1 to July 31, 2019, were recruited, and their hematological parameters were measured using Sysmex XN-1000 instrument. All obtained data were analyzed statistically.

RESULTS: From 100 malaria-positive patients, 87 patients, consisting of 57 P. vivax and 30 P. falciparum patients, met criteria. Anemia and parasite density $>50,000$ parasites $/ \mu \mathrm{L}$ were significantly higher in $P$. falciparum than $P$. vivax patients $(p<0.05)$ though hemoglobin concentration and parasite density were insignificantly different. Interestingly, basophil count was significantly higher in $P$. falciparum compared to $P$. vivax patients $(p=0.04)$. The eosinophil count was significantly higher in $P$. vivax $(p=0.01)$ than $P$. falciparum patients and indicated a significant positive correlation $(p=0.04, r=+0.28)$ with the parasite density.

CONCLUSION: There were significant differences between basophil and eosinophil count between $P$ vivax and $P$. falciparum infections. Eosinophil count showed a significant positive correlation with parasite density.
\end{abstract}

\section{Introduction}

Malaria remains one of the deadly infectious diseases that continue as serious public health problems worldwide, particularly in tropical countries. Around 219 million peoples suffered from malaria, and 445 thousand of them died [1]. Indonesia, the country with a high malaria burden, has committed to eradicating malaria in 2030 [2]. Instead, the latest report shows the increased cases of more than 100,000 malaria cases occurred between 2017 and 2016 in Indonesia [1].

Dynamic alterations of hematological parameters are common findings in malaria patients. They might attribute to some changes in significant blood cell types, including erythrocyte, leukocyte, and platelet [3], [4], [5], [6].
Hemoglobin, erythrocyte, total leukocyte, neutrophil, eosinophil, monocyte, and lymphocyte counts seemed significantly lower contrasted with non-malaria patients [3], [4]. Meanwhile, erythrocyte indices, neutrophillymphocyte ratio (NLR), and monocyte-lymphocyte ratio (MLR) were higher opposed to non-malaria patients [5], [7]. Leukocyte, neutrophil, monocyte, lymphocyte, erythrocyte, and platelet counts among different levels of parasitemia levels also marked to differ significantly [5].

Plasmodium falciparum and Plasmodium vivax are frequent causes of malaria worldwide, including in Indonesia [1]. Although both species are blood parasites, their biological characteristics, such as life cycle, virulence mechanisms, disease manifestation, and management, are dissimilar [8]. Their species-related consequences 
on hematological parameters have not been widely investigated. For instance, $P$. falciparum might result in more than $10 \%$ parasitemia, whereas $P$. vivax could only reach $2 \%$ [8]. Higher parasitemia would undoubtedly result in poor prognosis [9], [10]. However, severe $P$. vivax malaria cases have also been recorded [6], [11]. That evidence inferred that prompt species identification is necessary since both infections require different pharmacotherapeutic approaches. Unfortunately, the microscopic blood smear, the gold standard for diagnosing malaria, needs more extended time, and particular expertise to obtain the result [12]. Hematological parameter changes associated with parasite species-specific effects appear potential to provide a reference in specifically suspecting malaria species, even for estimating the total parasite burden of the disease in the endemic area, due to its availability in the routine examination. The present study aimed to investigate the comparison of hematological parameters between $P$. vivax- and $P$. falciparum-infected patients referred to Merauke General Hospital. The study also tried to correlate the parasite density and hematological parameters in each investigated group. Better understanding in this field could help physicians suspect parasite species in highly suspected malaria patients and predict patient prognosis so that the quick and specific management could be initiated, particularly in the endemic area with limited diagnostic facilities.

\section{Materials and Methods}

\section{Samples collection}

A cross-sectional study was conducted at Merauke General Hospital, Papua, Indonesia, from January to July 2019. Blood samples were collected from patients by vena punctured after signing the informed consent. Blood, then, was transferred to EDTA tubes for parasite and hematology examination. Patients with microscopically confirmed malaria of $P$. vivax or $P$. falciparum were engaged, whereas those with malaria mixed infection, immunocompromised, and comorbid infections were excluded.

\section{Malaria parasite examination}

Microscopic examinations were carried out on prepared Giemsa-stained thin and thick blood films to identify malaria species and quantify the parasite density based on the latest WHO guidelines [13]. The formula employed to quantify parasite density is written below.

Parasite density

$$
\left(\frac{\text { parasites }}{\mu \mathrm{L}}\right)=\frac{\sum \text { parasites }}{200 \text { observed }} \times \text { leukocyte count }
$$

The examination was accomplished by two trained and experienced field microscopists independently in Merauke clinical pathology laboratory. All obtained data were reassessed by the clinical pathologist at Merauke General Hospital.

\section{Hematology assay}

The hematology examination was performed using Sysmex XN-1000 (Sysmex Corporation, Kobe, Japan). The examination included hemoglobin concentration, erythrocyte count, mean corpuscular volume, mean corpuscular hemoglobin $(\mathrm{MCH}), \mathrm{MCH}$ concentration (MCHC), leukocyte and differential counts, NLR, MLR, and platelet count. All laboratory procedures were conducted based on appropriate standard operating procedures. Quality control of the instrument was completed per manufacturer standards. As parasite examination, all obtained data were reassessed by the clinical pathologist at Merauke General Hospital.

\section{Data analysis}

Normality distribution of data was analyzed using the Kolmogorov-Smirnov test if samples exceed 50 and the Shapiro-Wilk if samples were 50 or lesser. Our comparison hypothesis was proved by performing the independent t-test for normally distributed data. Otherwise, the Mann-Whitney U-test would be used. The proportion of data was analyzed using the $Z$ test. The Pearson correlation test was employed to test our correlation hypothesis if data were normally distributed, and the Spearman correlation test in case they did not. The finding was deemed significant at $p<0.05$ or $|\mathrm{Z}|>1.65$.

\section{Ethical declaration}

This study's ethical clearance was issued by the Medical Research Ethics Committee, Faculty of Medicine, Universitas Airlangga (No.169/EC/KEPK/ FKUA/2019).

\section{Results}

\section{General characteristics}

A total of 100 positive malaria samples were collected. However, six patients with mixed infection ( $P$. vivax/ $P$. falciparum) and seven patients with incomplete data were excluded. The study eventually involved $57(65.51 \%)$ cases of $P$. vivax and $30(34.48 \%)$ cases of $P$. falciparum infections. As many as, $64.37 \%$ of involved patients were male and 
became the predominant contributor of malaria cases, which comprised $64.91 \%$ of $P$. vivax and $63.33 \%$ of $P$. falciparum cases. The mean age of $P$. vivax and $P$. falciparum groups was $29.87 \pm 16.03$ and $29.08 \pm$ 15.33, respectively.

\section{Comparison of parasite density between $P$. vivax and $P$. falciparum infection}

The median of $P$. vivax and $P$. falciparum parasite density was 5902.04 (379.84-135,700.00) parasites/ $\mu \mathrm{L}$ and 9061.00 (54.48-1109.675) parasites/ $\mu \mathrm{L}$, respectively. The median between both species was insignificantly different $(p>0.05)$. Furthermore, parasite density data were grouped into three categories, as shown in Table 1, and noted for their proportion in each malaria species to be compared statistically. The proportion of the parasite density $>50,000$ parasites $/ \mu \mathrm{L}$ was significantly higher in $P$. falciparum compared to $P$. vivax $(|\mathrm{Z}|=1.87, \mathrm{p}=0.03)$.

Table 1: Parasite density between Plasmodium vivax and P. falciparum

\begin{tabular}{|c|c|c|c|c|c|c|}
\hline \multirow[t]{2}{*}{ Parasite density (parasites $/ \mu \mathrm{L}$ ) } & \multicolumn{4}{|c|}{ Number (\%) } & \multirow{2}{*}{$\begin{array}{l}\text { Z-score } \\
(95 \% \mathrm{Cl})\end{array}$} & \multirow[t]{2}{*}{$\mathrm{p}$-value } \\
\hline & $P . v$ & & $P . f a$ & parum & & \\
\hline Category $1(<10,000)$ & 37 & (64.91) & 16 & $(53.33)$ & 1.05 & 0.15 \\
\hline Category $2(10,000-50,000)$ & 15 & (26.32) & 7 & (23.33) & 0.30 & 0.38 \\
\hline Category $3(>50,000)$ & 5 & (8.77) & 7 & (23.33) & -1.87 & $0.03^{\mathrm{a}}$ \\
\hline Total & 57 & (100.00) & 30 & (100.00) & N/A & $N / A$ \\
\hline
\end{tabular}

N/A: Not applicable. $P$ falciparum: Plasmodium falciparum, P. vivax: Plasmodium vivax.

\section{Comparison of hematological parameters between $P$. vivax and $P$. falciparum infection}

This study found that both eosinophil and basophil count were significantly different between investigated groups. P. vivax group's basophil count was substantially lower compared to $P$. falciparum group ( $p=0.04)$. Still, $P$. vivax group's eosinophil count was significantly higher contrasted to $P$. falciparum group ( $p=0.01$ ) (Table 2). Nonetheless, hemoglobin concentration, erythrocyte indices, erythrocyte count, total leukocyte count, neutrophil count, lymphocyte count, monocyte count, platelet count, NLR, and MLR between both groups were considered insignificantly different $(p>0.05)$ (Table 2).

Table 2: Comparison of hematological parameters between $P$. vivax and $P$. falciparum infections

\begin{tabular}{llllll}
\hline Parameters & \multicolumn{7}{l}{ Mean \pm SD/Median (Min.-Max.) } & p-value \\
\cline { 2 - 5 } & $P$. vivax & \multicolumn{5}{c}{ P. falciparum } \\
\hline Hemoglobin $(\mathrm{g} / \mathrm{dL})$ & 12.60 & $(4.30-16.60)$ & 11.95 & \pm 2.78 & 0.29 \\
Erythrocyte $\left(\times 10^{6} / \mu \mathrm{l}\right)$ & 4.81 & \pm 0.76 & 4.56 & \pm 0.97 & $0.19^{\mathrm{b}}$ \\
$\mathrm{MCV}(\mathrm{fL})$ & 74.93 & \pm 8.88 & 75.82 & \pm 8.26 & $0.65^{\mathrm{b}}$ \\
$\mathrm{MCH}(\mathrm{pg} / \mathrm{cell})$ & 26.70 & $(14.50-32.90)$ & 25.50 & $(21.30-46.10)$ & 0.82 \\
$\mathrm{MCHC}(\mathrm{g} / \mathrm{dL})$ & 34.60 & $(25.80-38.40)$ & 34.65 & $(31.20-46.30)$ & 0.72 \\
Platelet $\left(\times 10^{3} / \mu \mathrm{L}\right)$ & 97.00 & $(24.00-481.00)$ & 92.00 & $(13.00-285.00)$ & 0.19 \\
Leukocyte $\left(\times 10^{3} / \mu \mathrm{L}\right)$ & 7.10 & $(3.14-17.03)$ & 6.48 & $(2.19-19.66)$ & 0.92 \\
Eosinophil $\left(\times 10^{3} / \mu \mathrm{L}\right)$ & 0.10 & $(0.00-3.48)$ & 0.05 & $(0.00-0.60)$ & $0.01^{\mathrm{c}}$ \\
Basophil $\left(\times 10^{3} / \mu \mathrm{L}\right)$ & 0.02 & $(0.00-0.11)$ & 0.03 & $(0.00-0.20)$ & $0.04^{\mathrm{c}}$ \\
Neutrophil $\left(\times 10^{3} / \mu \mathrm{L}\right)$ & 5.04 & $(2.12-14.00)$ & 5.69 & \pm 2.83 & 0.71 \\
Lymphocyte $\left(\times 10^{3} / \mu \mathrm{L}\right)$ & 1.05 & $(0.18-3.13)$ & 1.15 & $(0.33-4.05)$ & 0.20 \\
Monocyte $\left(\times 10^{3} / \mu \mathrm{L}\right)$ & 0.62 & \pm 0.40 & 0.57 & $(0.16-2.20)$ & 0.63 \\
NLR & 4.95 & $(1.40-18.27)$ & 4.75 & $(0.17-24.18)$ & 0.28 \\
MLR & 0.55 & \pm 0.29 & 0.47 & $(0.21-1.13)$ & 0.66 \\
\hline P. falciparum: Plasmodium falciparum, P. vivax: Plasmodium vivax, MCV: Mean corpuscular volume, \\
MCH: Mean corpuscular hemoglobin, NLR: Neutrophil-lymphocyte ratio, MLR: Monocyte-lymphocyte ratio.
\end{tabular}

Furthermore, the occurrence of anemia was significantly different between both species. Anemia conduced to occur in $P$. falciparum group contrasted to $P$. vivax group $(|Z|=2.48, p=0.01$ ) (Table 3 ). Nevertheless, the occurrence of leukocytosis, leukocytopenia, thrombocytosis, and thrombocytopenia was different insignificantly.

Table 3: Major hematological abnormalities in $P$. vivax and $P$. falciparum infection

\begin{tabular}{|c|c|c|c|c|c|c|}
\hline \multirow{3}{*}{$\begin{array}{l}\text { Major hematological } \\
\text { abnormalities } \\
\text { Anemia (Hb } \leq 11 \mathrm{~g} / \mathrm{dL})\end{array}$} & \multicolumn{4}{|c|}{ Number (\%) } & \multirow{2}{*}{$\begin{array}{l}\text { Z-score } \\
(95 \% \mathrm{Cl})\end{array}$} & \multirow[t]{2}{*}{$p$-value } \\
\hline & & & $P . f$ & parum & & \\
\hline & 12 & $(21.05)$ & 14 & $(46.67)$ & -2.48 & $0.01^{\mathrm{a}}$ \\
\hline Leukocytosis ( $>10,000$ cells $/ \mu \mathrm{L}$ ) & 7 & (12.3) & 6 & $(20.00)$ & -0.96 & 0.17 \\
\hline Leukopenia ( $<4000$ cells/ $/ \mathrm{L})$ & 4 & $(7.00)$ & 1 & $(3.00)$ & 0.70 & 0.24 \\
\hline $\begin{array}{l}\text { Thrombocytosis } \\
(>450,000 \text { cells } / \mu \mathrm{L})\end{array}$ & 1 & (1.75) & 0 & $(0.00)$ & 0.73 & 0.23 \\
\hline $\begin{array}{l}\text { Thrombocytopenia } \\
(<150,000 \text { cells } / \mu \mathrm{L})\end{array}$ & 41 & (71.93) & 24 & $(80.00)$ & -0.82 & 0.21 \\
\hline
\end{tabular}

falciparum, $P$. vivax: Plasmodium vivax.

\section{Correlation between parasite density and hematological parameters}

The parasite density and eosinophil count in $P$. vivax group indicated a significant positive correlation with $r=+0.28(p=0.04)$ (Table 2). Hemoglobin concentration, erythrocyte count and indices, platelet count, lymphocyte count, total leukocyte count, basophil count, neutrophil count, monocyte count, NLR, and MLR showed insignificant correlation. However, in P. falciparum group, neither parasite density nor hematological parameters seemed to correlate significantly.

\section{Discussion}

Hematological abnormalities become a prevailing hallmark during malaria and favor to be variable among studies. These diversities appear to be multifactorial in etiology, depending on the parasitic agent, host responses, and environment. $P$. vivax and $P$. falciparum are prevalent causes of malaria in Indonesia [1], while both species possess different characteristics, pathogenesis mechanisms, and therapeutic management [8]. Although the life cycle, biological aspects, and clinical manifestations between both parasites have been studied extensively, the parasite density might differ among endemic areas, and hematological differences resulting from different malaria species seem to lack evidence. This research was conducted based on issues that those species distinctiveness might result in parasite density and hematological parameter abnormalities, which probably own clinical significance in the endemic area. To the best of our knowledge, this was the first study comparing various hematological parameters of $P$. vivax and $P$. falciparum patients and correlating those parameters with the malaria parasite density in Indonesia, particularly in Papua. 
The primary cause of malaria in the Merauke was $P$. vivax followed by $P$. falciparum. Six patients with mixed infection ( $P$. vivax and $P$. falciparum) were unexpectedly observed. This result contrasts with the study in Jayapura, Papua, which was predominantly caused by $P$. falciparum [14]. Those males were likely to get malaria than females, and insignificant patients' age difference satisfied previous findings [3], [5] and seemed to associate with different occupational exposures.

High parasitemia is likely to occur in $P$. falciparum compared to $P$. vivax due to the parasite indiscrimination to infect all erythrocyte maturation stages, generate multiple infections, and perform rapid schizogony [8]. This study showed that the proportion of parasite density $>50,000$ parasites $/ \mu \mathrm{L}$ in $P$. falciparum was significantly higher as opposed to $P$. vivax infection $(|Z|=1.87, p=0.03)$ (Table 1$)$. This study's highest parasite density was 135,700 parasites/ $\mu \mathrm{L}$ for $P$. vivax and 1109.675 parasites $/ \mu \mathrm{L}$ for $P$. falciparum. This finding of parasite propensity concords the previous study reported by Barber et al. [10]. Nevertheless, the median of parasite density between both groups was not statistically different. This finding might happen since the evidence of $P$. falciparum-infected erythrocyte performing cytoadherence have been reported [15], [16], resulting in parasite sequestration and preventing circulating parasite to represent the total parasite biomass. Notwithstanding, the present study still confirms the tendency and ability of $P$. falciparum to result in very high parasitemia.

As parasite density relates to the severity of malaria infection [9], [10], it is necessary to correlate the parasite density in each species with common examined hematological parameters. Although, none variables posed a significant correlation, except for eosinophil count in $P$. vivax infection. The parasite density showed significant positive correlation with eosinophil count $(r=$ $0.28, p=0.04$ ) (Table 4). These results appear contrary to some studies that indicated several significant correlations. An inverse correlation between the parasite densities with the lymphocyte count in $P$. falciparum

Table 4: Correlation between parasite density and hematological parameters in $P$. vivax and $P$. falciparum infection

\begin{tabular}{|c|c|c|c|c|}
\hline \multirow[t]{2}{*}{ Parameters } & \multicolumn{2}{|l|}{ P. vivax } & \multicolumn{2}{|l|}{ P. falciparum } \\
\hline & $\begin{array}{l}\text { Correlation } \\
\text { coefficient }\end{array}$ & $p$-value ${ }^{a}$ & $\begin{array}{l}\text { Correlation } \\
\text { coefficient }\end{array}$ & $p$-value ${ }^{a}$ \\
\hline \multicolumn{5}{|c|}{ Parasite density (parasite/ $/ \mathrm{L}$ ) } \\
\hline Hemoglobin & -0.20 & 0.15 & 0.13 & 0.50 \\
\hline Erythrocyte & -0.13 & 0.33 & 0.07 & 0.71 \\
\hline MCV & -0.11 & 0.43 & 0.14 & 0.47 \\
\hline $\mathrm{MCH}$ & -0.16 & 0.25 & 0.18 & 0.35 \\
\hline $\mathrm{MCHC}$ & -0.15 & 0.26 & 0.24 & 0.20 \\
\hline Platelet & -0.13 & 0.34 & -0.08 & 0.68 \\
\hline Leukocyte & 0.14 & 0.32 & 0.16 & 0.40 \\
\hline Eosinophil & 0.28 & $0.04^{\mathrm{b}}$ & -0.16 & 0.39 \\
\hline Basophil & 0.20 & 0.14 & -0.11 & 0.56 \\
\hline Neutrophil & 0.07 & 0.59 & 0.26 & 0.17 \\
\hline Lymphocyte & -0.04 & 0.76 & -0.17 & 0.37 \\
\hline Monocyte & 0.13 & 0.34 & -0.13 & 0.51 \\
\hline NLR & 0.13 & 0.34 & 0.29 & 0.12 \\
\hline MLR & 0.18 & 0.18 & -0.05 & 0.78 \\
\hline
\end{tabular}

infection and positive correlations of the parasite density with neutrophil and platelet counts in $P$. vivax and $P$. falciparum infection were reported by studies in Ghana and South Ethiopia [3], [7]. A mathematical model study also designated good relationships of the parasite density with neutrophil, lymphocyte, monocyte, and eosinophil count in $P$. falciparum infection [17]. Despite those discordances, insignificant correlations of parasite density, in both species, with hemoglobin concentration, leukocyte count, and monocyte count, in this study, agree with the previous studies [3], [7]. Interestingly, the positive correlation of eosinophil count and parasite density in $P$. vivax group seems becoming a new finding referring to those studies.

Interplays of parasite and hematological parameters still require further elucidation. Intriguing reasons that might underlie insignificant correlations influence malaria transmission, sequestration, and systemic inflammatory reactions [15], [18], [19]. Proinflammatory cytokines generated during $P$. falciparum infection promote endothelial activation, leading to leukocyte adherence and sequestration, microvascular thrombosis, and endothelial injury (increased platelet usage) [10], [19], [20], [21], [22]. They might explain why the significant positive correlation of eosinophil and the parasite density, in this study, only occurred in $P$. vivax infection since severe inflammatory reactions during $P$. vivax infection are unlikely to occur [8], [20]. However, the reasons for eosinophil roles during malaria are still controversial. They have been associated with an antiparasitic activity, disease recovery, hypersensitivity, and total parasite burdens [23], [24], [25], [26].

Anemia is frequently observed and associated with malaria severity. However, its exact mechanism seems intricate and poorly understood. As the parasites invade erythrocytes, hemolysis will be occurring and lead to anemia. Nonetheless, the loss of uninfected erythrocytes (UE) appears more influential in the anemia pathogenesis. The previous studies inferred that either mechanical or immune-mediated splenic clearance was principal underlying causes of massive UE loss [27], [28]. Bone marrow suppression was also responsible for the anemia occurrence [29], [30]. The anemia (hemoglobin $<11 \mathrm{~g} / \mathrm{dL}$ ) in both $P$. vivax and $P$. falciparum was noted in our study. It favored in $P$. falciparum compared to $P$. vivax $(|Z|=2.48, p=0.01)$ (Table 3). Erythrocyte profiles in $P$. falciparum, however, did not significantly differ from $P$. vivax (Table 2). This result argues the earlier study that found significant differences in erythrocyte count and indices, even if it strengthens the finding of the insignificant hemoglobin concentration difference in both species [5], [11]. These results possibly happen as different research settings might possess different local parasitic strains and malaria transmission intensity. Evidence of $P$. falciparum-infected erythrocyte sequestration [15], [16] makes measured circulating erythrocyte profiles unable to figure out actual states. 
The leukocyte deems as the significant element of the immune system that deals with the plasmodia invasion. It prefers to change, meeting on needs and agent properties dynamically. Theoretically, massive schizont ruptures, particularly in $P$. falciparum, will be followed by the extensive exposure with intraerythrocytic materials and parasite antigens, driving to profound immune responses [31]. Our finding has met the theory that leukocytosis (leukocyte $>10,000$ cells/ $\mu \mathrm{L}$ ) favored occurring in $P$. falciparum rather than $P$. vivax although it was statistically insignificant. That leukocytopenia (leukocyte $<4000$ cells $/ \mu \mathrm{L}$ ) was found more in $P$. vivax (Table 3) which was in contrast with a report in Thailand during 1998-1999 [32]. Furthermore, leukocyte profiles, such as total leukocyte count, neutrophil count, lymphocyte count, monocyte count, NLR, and MLR, noted insignificant differences between groups. Nevertheless, the significant difference of eosinophil count $(p=0.01)$ and insignificant differences of total leukocyte, lymphocyte, and monocyte counts still followed an investigation in Thailand [5]. That basophil count marked to be significantly different $(p=0.04)$ between observed groups may become a new finding referring to that study. Unimportant differences of NLR and MLR between both species were found, although the previous result showed significant differences compared to non-malaria patients [4].

Inconsistent findings of leukocyte profiles between investigated groups are not unlikely. Microvascular endothelial activation, induced by increased pro-inflammatory cytokines, such as tumor necrosis factor- $\alpha$ and interleukin (IL)- $1 \beta$, leads to overexpression of intercellular adhesion molecule- 1 and secretion of IL-8, a potent neutrophil attractant [31], [33]. They promote leukocytes marginalization and sequestration [21], resulting in discrepancies between circulating and actual total leukocyte count. That the basophil count appeared higher in $P$. falciparum than in $P$. vivax patients may support the finding of $P$. falciparum ability to produce histamine-releasing factors, belonging to translationally controlled tumor protein (TCTP), suggesting important roles in regulating basophil and eosinophil activity [26], [34]. A study in Senegal reported a higher concentration of $P$. falciparum TCTP in patients with severe malaria than mild malaria and healthy control [35]. That study also identified the enhanced basophil reactivity to stimuli associated with $P$. falciparum TCTP in vivo and with malaria severity [36]. TCTP might also reflect total parasite burdens (including sequestered parasite) rather than peripheral parasitemia [26]. This mechanism explains why both parasite densities in our research do not exhibit significant differences regarding the discovery of a considerable difference in eosinophil and basophil count in investigated species. However, the eosinophil count was higher in $P$. vivax than $P$. falciparum might indicate other different $P$. vivax pathogenesis processes that need further elucidation.

Another common complication of malaria is thrombocytopenia. Itspathogenesishasnotbeencertainly ascertained. Platelet-mediated erythrocyte clumping, von Willebrand factor adherence, sequestration, and immune-mediated destruction are responsible for thrombocytopenic episodes [22], [35], [37], [38], [39]. That thrombocytopenia ( $<150,000$ cells/ $\mu \mathrm{L})$ was still a common finding was confirmed in this study $(>70 \%$ of patients in both groups), and its proportion of both species was roughly similar (Table 3 ), as reported in another study [4]. A thrombocytosis case was only discovered in $P$. vivax group. Nonetheless, the comparison of platelet count between investigated species was not significantly different, in contrast with the previous investigation in Thailand [5].

This study's limitation was no assessment of primary confounding factors affecting hematological parameters such as the engaged patient's genetic susceptibilities and micronutrient state. That the parasite examination only relied on microscopy also makes submicroscopic malaria unrecognized and could lead to underestimation of parasite density impact on hematological parameters.

\section{Conclusion}

Diversities of hematological abnormalities during malaria are common findings. Anemia, leukocyte count abnormalities, and thrombocytopenia are predominant and favor to be in $P$. falciparum infection. Several parameters do not differ significantly between $P$. vivax and $P$. falciparum. However, basophil count is significantly higher in $P$. falciparum infection, whereas eosinophil count is significantly higher in $P$. vivax infection. These findings suggest that basophil and eosinophil count possesses clinical values and might provide a clue, together with clinical presentations, to suspect $P$. vivax or $P$. falciparum infection in the endemic area. The significant positive correlation between the parasite density and eosinophil count in $P$. vivax may be the potential to predict the total parasite burden. These findings offer the opportunity to conduct prompt and specific management, particularly in regions with limited diagnostic facilities. Furthermore, since this report is a pioneer study in Merauke, Papua, researches concerning this topic should be more encouraged.

\section{Acknowledgment}

The authors would like to acknowledge Simlitabmas Program by KEMENRISTEKDIKTI RI (Ministry of Research, Technology, and Higher Education of the Republic of Indonesia) to support this study (contract number: 544/UN3.14/LT/2019). We 
are also grateful to Merauke General Hospital, sample collectors, study participants, and all who gave their hands so that this study could be done.

\section{References}

1. World Health Organization. Malaria Report, 2018. Geneva: World Health Organization; 2018.

2. Kementerian Kesehatan Republik Indonesia. Situasi Terkin Perkembangan Program Pengendalian Malaria di Indonesia Tahun 2018. Jakarta: Kementerian Kesehatan Republik Indonesia; 2018.

3. Awoke N, Arota A. Profiles of hematological parameters in Plasmodium falciparum and Plasmodium vivax malaria patients attending Tercha general hospital, Dawuro Zone, South Ethiopia. Infect Drug Resist. 2019;12:521-7. https://doi.org/10.2147/idr. s184489

\section{PMid:30881057}

4. Kotepui M, Phunphuech B, Phiwklam N, Chupeerach C, Duangmano S. Effect of malarial infection on hematological parameters in population near Thailand-Myanmar border. Malar J. 2014;13(1):218-24. https://doi.org/10.1186/1475-2875-13-218 PMid:24898891

5. Kotepui M, Piwkham D, Phunphuech B, Phiwklam N, Chupeerach C, Duangmano S. Effects of malaria parasite density on blood cell parameters. PLoS One. 2015;10(3):e0121057. https://doi.org/10.1371/journal.pone.0121057

PMid:25807235

6. Arévalo-Herrera M, Lopez-Perez M, Medina L, Moreno A, Gutierrez JB, Herrera S. Clinical profile of Plasmodium falciparum and Plasmodium vivax infections in low and unstable malaria transmission settings of Colombia. Malar $\mathrm{J}$. 2015;14(1):154-64. https://doi.org/10.1186/s12936-015-0678-3

7. Antwi-Baffour S, Kyeremeh R, Buabeng D, Adjei JK, Aryeh C, Kpentey $\mathrm{G}$, et al. Correlation of malaria parasitemia with peripheral blood monocyte to lymphocyte ratio as indicator of susceptibility to severe malaria in Ghanaian children. Malar J. 2018;17(1):419-27. https://doi.org/10.1186/s12936-018-2569-x PMid:30419923

8. Garcia LS. Diagnostic Medical Parasitology. $6^{\text {th }}$ ed. Washington, DC: ASM Press; 2016.

9. Argy N, Kendjo E, Augé-Courtoi C, Cojean S, Clain J, Houzé P. Influence of host factors and parasite biomass on the severity of imported Plasmodium falciparum malaria. PLoS One. 2017;12(4):e0175328. https://doi.org/10.1371/journal. pone. 0175328

PMid:28410415

10. Barber BE, William T, Grigg MJ, Parameswaran U, Piera KA, Price RN, et al. Parasite biomass-related inflammation, endothelial activation, microvascular dysfunction, and disease severity in Vivax malaria. PLoS Pathog. 2015;11(1):e1004558. https://doi.org/10.1371/journal.ppat.1004558 PMid:25569250

11. Abdallah TM, Abdeen MT, Ahmed IS, Hamdan HZ, Magzoub M, Adam I. Severe Plasmodium falciparum and Plasmodium vivax malaria among adults at Kassala hospital, Eastern Sudan. Malar J. 2013;12(1):148-54. https://doi.org/10.1186/1475-2875-12-148

12. Tangpukdee N, Duangdee $C$, Wilairatana P, Krudsood S. Malaria diagnosis: A brief review. Korean J Parasitol. 2009;47(2):93102. https://doi.org/10.3347/kjp.2009.47.2.93

PMid:19488414
13. World Health Organization. Basic Malaria Microscopy, Part 1. $2^{\text {nd }}$ ed. Geneva: World Health Organization; 2010.

14. Sorontou Y, Asih PB, Wanandi SI, Ramelan W, Syafruddin D. Malaria in Jayapura District, Papua Province, Indonesia, and resistance to sulfadoxine-pyrimethamine. Med J Indones. 2007;16(1):32-8. https://doi.org/10.13181/mji.v16i1.254

15. David PH, Hommel M, Miller LH, Udeinya IJ, Oligino LD. Parasite sequestration in Plasmodium falciparum malaria: Spleen and antibody modulation of cytoadherence of infected erythrocytes. Proc Natl Acad Sci U S A. 1983;80(16):5075-9. https://doi.org/10.1073/pnas.80.16.5075 PMid:6348780

16. Safeukui I, Correas JC, Brousse V, Hirt D, Deplaine G, Mulé S, et al. Retention of Plasmodium falciparum ring-infected erythrocytes in the slow, open microcirculation of the human spleen. Blood. 2008;112(6):2520-8. https://doi.org/10.1182/ blood-2008-03-146779 PMid: 18579796

17. Evelyn ME, Ezeiruaku FC, Ukaji DC. Experiential relationship between malaria parasite density and some haematological parameters in malaria infected male subjects in port Harcourt, Nigeria. Glob J Health Sci. 2012;4(4):139-48. https://doi. org/10.5539/gjhs.v4n4p139

PMid:22980350

18. Ademolue TW, Aniweh Y, Kusi KA, Awandare GA. Patterns of inflammatory responses and parasite tolerance vary with malaria transmission intensity. Malar J. 2017:16(1):145-157. https://doi.org/10.1186/s12936-017-1796-x PMid:28399920

19. Coban C, Lee MS, Ishii KJ. Tissue-specific immunopathology during malaria infection. Nat Rev Immunol. 2018;18(4):266-78. https://doi.org/10.1038/nri.2017.138 PMid:29332936

20. Day NP, Hien TT, Schollaardt T, Loc PP, Chuong LV, Chau TT, et al. The prognostic and pathophysiologic role of proand antiinflammatory cytokines in severe malaria. J Infect. 1999;180(4):1288-97. https://doi.org/10.1086/315016 PMid: 10479160

21. Hearn J, Rayment N, Landon DN, Katz DR, de Souza JB. Immunopathology of cerebral malaria: Morphological evidence of parasite sequestration in murine brain microvasculature. Infect Immun. 2000;68(9):5364-76. https://doi.org/10.1128/ iai.68.9.5364-5376.2000 PMid: 10948166

22. Graham SM, Chen J, Chung DW, Barker KR, Conroy AL, Hawkes MT, et al. Endothelial activation, hemostasis, and thrombosis biomarkers in Ugandan children with severe malaria participating in a clinical trial. Malar J. 2016;15(1):56-64. https:// doi.org/10.1186/s12936-016-1106-z

23. Waters LS, Taverne J, Tai P, Spry CJ, Targett GA, Playfair JH Killing of Plasmodium falciparum by eosinophil secretory products. Infect Immun. 1987;55(4):877-81. https://doi. org/10.1128/iai.55.4.877-881.1987

PMid:3549562

24. Kurtzhals JA, Reimert CM, Tette E, Dunyo SK, Koram KA, Akanmori BD, et al. Increased eosinophil activity in acute Plasmodium falciparum infection-association with cerebral malaria. Clin Exp Immunol. 1998;112(2):303-7. https://doi. org/10.1046/j.1365-2249.1998.00586.x PMid:9649195

25. Camacho LH, Wilairatana P, Weiss G, Mercader MA Brittenham GM, Looareesuwan S, etal. The eosinophilic response and haematological recovery after treatment for Plasmodium falciparum malaria. Trop Med Int Health. 1999;4(7):471-5. https://doi.org/10.1046/j.1365-3156.1999.00426.x 


\section{PMid:10470337}

26. Mecheri S. Contribution of allergic inflammatory response to the pathogenesis of malaria disease. Biochim Biophys Acta Mol Basis Dis. 2012;1822(1):49-56. https://doi.org/10.1016/j. bbadis.2011.02.005

27. Huang S, Amaladoss A, Liu M, Chen H, Zhang R, Preiser PR, et al. In vivo splenic clearance correlates with in vitro deformability of red blood cells from Plasmodium yoeliiinfected mice. Infect Immun. 2014;82(6):2532-41. https://doi. org/10.1128/iai.01525-13

PMid:24686065

28. Safeukui I, Gomez ND, Adelani AA, Burte F, Afolabi NK, Akondy R, et al. Malaria induces anemia through CD8+ $T$ cell-dependent parasite clearance and erythrocyte removal in the spleen. mBio. 2015;6(1):e02493-14. https://doi.org/10.1128/mbio.02493-14 PMid:25604792

29. Casals-Pascual C, Kai O, Cheung JO, Williams S, LoweB, Nyanoti M, et al. Suppression of erythropoiesis in malarial anemia is associated with hemozoin in vitro and in vivo. Blood. 2006;108(8):2569-77. https://doi.org/10.1182/blood-2006-05-018697 PMid: 16804108

30. Panichakul T, Payuhakrit W, Panburana P, Wongborisuth $\mathrm{C}$, Hongeng S, Udomsangpetch R. Suppression of erythroid development in vitro by Plasmodium vivax. Malar J. 2012;11(1):173-80. https://doi.org/10.1186/1475-2875-11-173

31. Abbas A, Lichtman A, Pillai S. Cellular, and Molecular Immunology. $9^{\text {th }}$ ed. Philadelphia, PA: Elsevier; 2018.

32. McKenzie FE, Prudhomme WA, Magill JA, Forney JA, Permpanich B, Lucas C, et al. White blood cell counts and malaria. J Infect. 2005;192(2):323-30. https://doi.org/10.1086/431152 PMid:15962228

33. Chakravorty SJ, Carret C, Nash GB, Ivens A, Szestak T, CraigAG. Altered phenotype and gene transcription in endothelial cells, induced by Plasmodium falciparum-infected red blood cells: Pathogenic or protective? Int J Parasitol. 2007;37(8-9):975-87. https://doi.org/10.1016/j.ijpara.2007.02.006

\section{PMid: 17383656}

34. MacDonald SM, Bhisutthibhan J, Shapiro TA, Rogerson SJ Taylor TE, Tembo $\mathrm{M}$, et al. Immune mimicry in malaria: Plasmodium falciparum secretes a functional histaminereleasing factor homolog in vitro and in vivo. Proc Natl Acad Sci U S A. 2001;98(19):10829-32. https://doi.org/10.1073/ pnas.201191498

PMid:11535839

35. Coelho HC, Lopes SC, Pimentel JP, Nogueira PA, Costa FT, Siqueira AM, et al. Thrombocytopenia in Plasmodium vivax malaria is related to platelets phagocytosis. PLoS One. 2013;8(5):e63410. https://doi.org/10.1371/journal. pone.0063410

PMid:23723981

36. Pelleau S, Diop S, Badiane MD, Vitte J, Beguin P, Nato F, et al. Enhanced basophil reactivities during severe malaria and their relationship with the Plasmodium falciparum histamine-releasing factor translationally controlled tumor protein. Infect Immun. 2012;80(8):2963-70. https://doi.org/10.1128/iai.00072-12 PMid:22753372

37. Pain A, Ferguson DJ, Kai O, Urban BC, Lowe B, Marsh K, et al. Platelet-mediated clumping of Plasmodium falciparuminfected erythrocytes is a common adhesive phenotype and is associated with severe malaria. Proc Natl Acad Sci U S A. 2001;98(4):1805-10. https://doi.org/10.1073/pnas.98.4.1805 PMid: 11172032

38. Grau GE, Mackenzie CD, Carr RA, Redard M, Pizzolato G, Allasia C, et al. Platelet accumulation in brain microvessels in fatal pediatric cerebral malaria. J Infect. 2003;187(3):461-6. https://doi.org/10.1086/367960

PMid: 12552430

39. O'Sullivan JM, Preston RJ, O'Regan N, O'Donnell JS. Emerging roles for hemostatic dysfunction in malaria pathogenesis. Blood. 2016;127(19):2281-8. https://doi.org/10.1182/ blood-2015-11-636464

PMid:26851291 